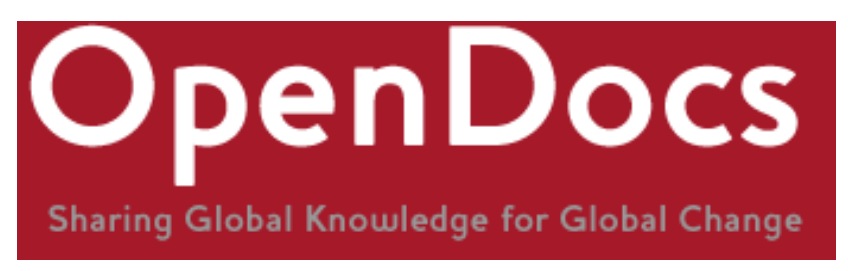

Title: From field to factory: Tracing bonded labour in the Coimbatore powerloom industry, Tamil Nadu.

Citation: Carswell, Grace M and De Neve, Geert (2013) From field to factory: Tracing bonded labour in the Coimbatore powerloom industry, Tamil Nadu. Economy and Society, 42 (3), pp. 430-454. DOI:10.1080/03085147.2013.772757.

Official URL: http://dx.doi.org/10.1080/03085147.2013.772757

More details/abstract: Taking a historical perspective this paper explores the phasing out of 'bonded' labour in agriculture and its reappearance in the village-based powerloom industry in the Tiruppur region of Tamil Nadu, India.

Focussing on a village outside Tiruppur, we trace the gradual transformation, and ultimate disappearance of forms of labour bondage in agriculture. In this region bondedness in agriculture changed in a number of significant ways, before giving way by about the 1970 s to primarily casual and contract-based labour arrangements. Around the same time, small-scale powerloom workshops, which are highly labour intensive and increasingly dependent on migrant labour, began to mushroom in the village, leading to the reintroduction of bonded labour, but this time in the context of rural industrial employment. We explore how debt bondage was introduced and how it affects the working lives of both migrants and nonmigrants. The paper examines the differences and similarities between past agricultural and current industrial labour bondage, and how it is experienced and talked about by both employers and workers.

Version: Accepted version

Terms of use: This is an Accepted Manuscript of an article published by Taylor \& Francis Group in Economy and Society on 25/08/2013, available online: http://dx.doi.org/10.1080/03085147.2013.772757.

This is a download from OpenDocs at the Institute of Development Studies

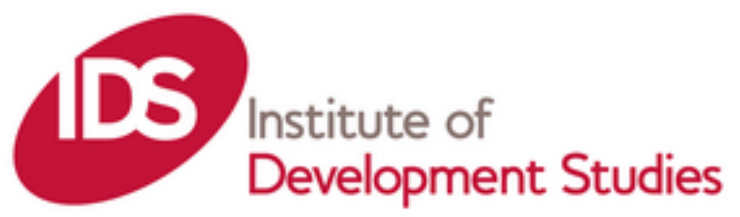




\title{
From Field to Factory: Tracing transformations in bonded labour in the Tiruppur region, Tamil Nadu
}

\author{
Geert De Neve (Department of Anthropology, University of Sussex) \\ Grace Carswell (Department of Geography, University of Sussex) ${ }^{1}$
}

\begin{abstract}
Taking a historical perspective this paper explores the phasing out of 'bonded' labour in agriculture and its reappearance in the village-based powerloom industry in the Tiruppur region of Tamil Nadu, India. Focussing on a village outside Tiruppur, we trace the gradual transformation, and ultimate disappearance of forms of labour bondage in agriculture. In this region bondedness in agriculture changed in a number of significant ways, before giving way by about the 1970s to primarily casual and contract-based labour arrangements. Around the same time, small-scale powerloom workshops, which are highly labour intensive and increasingly dependent on migrant labour, began to mushroom in the village, leading to the reintroduction of bonded labour, but this time in the context of rural industrial employment. We explore how debt bondage was introduced and how it affects the working lives of both migrants and non-migrants. The paper examines the differences and similarities between past agricultural and current industrial labour bondage, and how it is experienced and talked about by both employers and workers.
\end{abstract}

\section{Introduction: Unfree labour in India}

The debate on unfree labour in India has received renewed attention over the last few years. Both academics and policy makers are seeking to better understand the pervasiveness of this practice on the subcontinent as well as the specific forms it takes under contemporary capitalist modes of production (see for example Brass 2008; ILO 2005; Lerche 2007; Breman, Guérin and Prakash 2009; Srivastava 2005). Alongside research that seeks to document the spread and diversity of bonded labour practices, there is also a need to understand both the wider social structures and the political economy of capitalism, which contribute to the persistence of such practices in India today (Lerche 2007). Srivastava, among others, has pointed to the high incidence of bonded labour outside agriculture and the high incidence of migrant labour bondage (2009:

\footnotetext{
${ }^{1}$ Twelve months field research was carried out from July 2008-July 2009 in Tiruppur District, Tamil Nadu, funded by a DFID-ESRC Research Award (RES-167-25-0296). The research would not have been possible without the assistance of our research assistants - most especially Gayathri, Arul, Muthu and Priya. Earlier versions of this paper were presented at the University of Manchester and at the 2010 ECMSAS in Bonn. We thank the participants in these meetings for valuable comments and are particularly grateful to Jan Breman, Judith Heyer, Jens Lerche, Jonathan Pattenden, Nicola Phillips, Ravi Srivastava, and Karen Sykes for feedback.
} 
135), both of which effectively map onto those sectors of India's informal economy that have massively expanded in the neo-liberal era.

Within the literature there is a considerable degree of agreement that the contemporary reproduction of debt bondage and bonded labour relations is closely related to the rise in circulatory and seasonal migrant labour flows, the increasingly crucial role played by labour recruiters and intermediaries, and the soaring levels of indebtedness and continued marginalisation at the lowest echelons of Indian society (Breman and Guérin 2009; Picherit 2009; Srivastava 2009). Moreover, there is a widespread sense that bonded labour and the payment of large cash advances contribute to the depressing of wage levels, or at least that bondedness goes hand in hand with the postponement of payment and with the payment of wages below minimum levels, especially for migrant workers (Srivastava 2009; Guérin 2009). In addition to the depressing of wage levels, there is evidence that labour bondage is particularly prevalent among the lowest and most oppressed sections of rural society, who are forced to migrate for work due to declining agricultural incomes and a general lack of employment alternatives back home (Guérin 2009; Picherit 2009).

This paper seeks to make an empirical and analytical contribution to this debate by focusing on a case study from western Tamil Nadu in southern India, where a history of labour bondage in agriculture has given way to new forms of bondage in rural industry. It is in the rural powerloom sector, which has expanded over the last three decades, that the tying of labour through cash advances and debt is most prevalent today. The case study presents us with a social and economic context that differs from existing comparative studies in at least three ways.

First, the case study is located in the Tiruppur hinterland, a highly industrialised part of western Tamil Nadu that is known for serious labour shortages and a tightening of rural and urban labour markets (Heyer 2009; 2010a). In the Tiruppur region, the garment and textile industries, along with their many ancillary activities, provide a wide range of employment opportunities alongside agriculture. However, tightening labour markets and intense competition over labour have not led to uniform improvements for workers or an undifferentiated increase in labour's bargaining power. Rather, in the rural powerloom sector, it has led high caste employers to try and tie labour through debt and prevent a mass labour drain from the village powerlooms to garment companies in nearby Tiruppur.

Secondly, the rural powerloom industry in the region employs both local villagers and migrant workers from neighbouring districts. Unlike other sectors that are marked by seasonality and rely heavily on circular migration flows, the powerloom industry requires a constant and stable labour input throughout the year. As a result employers try to recruit both locals and migrants on a long-term basis; they seek to attract them with cash advances and immobilise them through debt bondage. Thirdly, although wages in the rural powerloom industry are certainly not high, they are above minimum wage levels, are higher than 
agricultural wages, and remain unrelated to the level of cash advances handed out to each individual worker (unlike Kapadia 1995; Guérin et al 2009). Even so, both employers and workers have their reasons for giving and receiving advances.

We note at the outset that not every worker who receives an advance payment from an employer can be described as unfree, nor is every indebted labourer a bonded labourer. Contractual labour relations routinely rely on advance payments and on fixed-term commitments to a stipulated contract (Breman and Guérin 2009: 7). What needs to be recognised within any debate on unfree labour is the huge diversity of bonded labour situations, or what Guérin has called the 'continuum' from milder to worse forms of bondedness in contemporary India (2009: 237). It is not the advance or debt in itself that leads to bondedness but the nature of the labour relationship it produces. Advances lead to bondage when they capture a labourer into a debt trap, are accompanied by harsh labour conditions and exploitative wages, are buttressed by violence and coercion, and curtail a worker's bargaining power and ability to access alternative employment. Even if voluntarily entered, debt can lead to forms of bondage that remove workers' control over their own labour and ties them into bonds they can no longer escape. The advance payments described in this article certainly fit such a description of debt bondage, even if - as discussed below - cash advances are voluntarily accepted and often even asked for by workers themselves.

Taking a historical perspective that traces the gradual disappearance of labour bondage in agriculture and the subsequent introduction of debt bondage in the powerloom industry, the paper seeks to make three points. Firstly, it illustrates how the reproduction of labour bondage - over time and across rural sectors - is central to the ways in which a dominant caste (of land- and powerloom-owning Gounders) seeks to retain and remould its control over a low caste labour force in a context of rapidly tightening labour markets. Secondly, it is argued, in line with other scholars, that there is a degree of compatibility between contemporary forms of debt bondage and capitalist production (Breman 1993, Lerche 2007, Brass 1994; 1999). In the context of neo-liberal economic reform, even advanced forms of capitalist production clearly seek to de-commodify or deproletarianise particular sections of the labour force. De-proletarianisation, as described by Brass, refers to a process in which labour is prevented from functioning as a free proletariat (able to sell its labour when and where it wishes) and in which the commodification of labour is curtailed through forms of worker attachment and unfreedom (Brass 1990: 37). Thirdly, labour's own position towards debt bondage can be highly ambivalent: while workers realise that debt binds them, social obligations and pressures of status and consumption simultaneously force workers to take on ever larger amounts of debt. What this article ultimately seeks to demonstrate is that bonded labour can be reproduced in regions marked by rapid but highly uneven development. Such uneven development occurs even in those places - like the Tiruppur industrial region in 
south India - that are widely presented as economic successes. Where different sections of capital (urban versus rural, or garments versus powerlooms) compete over labour, employers seek to immobilise sections of the regional labour force; and where overall levels of development and economic wealth are relatively high, pressures on labour to take on debt in order to fulfil obligations towards family and kin are also high.

\section{Bonded labour in agriculture: from pannaiyaal to casual and contractual worker}

Bonded labour has a long history in the Coimbatore region of Tamil Nadu. Early records include that by Francis Buchanan who travelled through the area in 1801 and noted that labourers were advanced a combination of cash and grain at the beginning of the year, and given a place to live. If workers were unable to repay the advance by the end of the year, the landowner would not allow them to leave. This, Cederlöf (1997: 44) notes, suggests that labour employment with a system of advances was not introduced during the British era, but had its roots in the region before the arrival of colonial power. The degree to which such arrangements worked to the advantage of workers, or to the advantage of landowners, and how this changed over time, has been examined by Washbrook. He notes that while in the late nineteenth century the system of advances was probably 'oppressive', earlier, in the eighteenth century, the balance of power between labour and capital was very different. Levels of advances were very high and employers' ability to control workers was limited. Washbrook argues that the last decades of the eighteenth century were the 'Golden Age' for labouring groups, while the nineteenth century saw the beginning of 'agricultural labour's long march into "modern" destitution' (Washbrook 1993: 79).

How important were such 'tied' agricultural labourers, and how did their numbers change over time? Baker notes dramatic increases of pannaiyaal (permanent farm servants) across Tamil Nadu from the late eighteenth century to the 1930s and according to Cox's Gazetteer of $193328 \%$ of the rural labour force was permanently employed as 'farm servants' (cited in Cederlöf 1997:50). There is evidence that in the Coimbatore region of Tamil Nadu, where our case study villages are located, the system of pannaiyaal flourished till much later than in other regions. Drawing on her study of the Palladam ${ }^{2}$ area of Coimbatore district, Cederlöf argues that the expansion of commercial crops and industrial processing of cotton from 1900 to 1930 'probably led to the rising numbers of permanently employed labourers on the farms' (1997: 113). Increases in irrigated crops and number of wells intensified the need to employ more permanent farm hands, and the Matharis, the main Dalit community in the region, joined the rising number of pannaiyaal in the agricultural workforce (1997: 113). By contrast, in other parts of Tamil Nadu, the number of permanent farm servants began to

\footnotetext{
${ }^{2}$ Palladam is a smaller town located about $16 \mathrm{~km}$ to the south of Tiruppur.
} 
dwindle during the same period. Basu, for example, reports that bonded labour among the Dalit caste of Paraiyars in the Chingleput district declined as landlords began to migrate to the cities in the early decades of the twentieth century. Moreover, intensification of agriculture and the opening up of labour markets outside the villages led to the reorganisation of labour (including an increased reliance on causal labour and tenants), emigration and the loosening of local bonds (Basu 2009: 52-60). Interestingly, for those left behind, this led to an increase in wage rates and a curtailment of working hours. In the dry area around Tiruppur, such changes did not occur until the 1940-50s and even more so from the 1970s when new urban and industrial opportunities began to turn the permanent farm servant into a less attractive option for both landlords and agricultural workers alike.

In the Tiruppur region, a first wave of change occurred from the late 1940s, when two factors let to a dramatic decline in the number of pannaiyaal. Firstly, from 1947-53 there was a drought, while around the same time the process of electrification of the countryside occurred. Cederlöf argues that the drought was 'decisive in the rapid decline of the employment of pannaiyaal', as water shortages made year-round cultivation and the employment of permanent labourers less attractive (1997:144). Secondly, at the time of the drought electricity was just becoming available in the villages, and the drought is likely to have acted as a spur to invest in electrification of irrigation (ibid.; 247). Electric pumpsets could be used day and night to irrigate more land, while replacing the manpower previously needed for irrigation. These combined factors led to a drastic decline in employment of pannaiyaal, whose earlier task consisted of managing the bucket and cattle irrigation system. By 1954 an Agricultural Labour Enquiry estimated that only 5 per cent of agricultural labourers were 'attached' labourers across the Madras state (ibid.: 148). Lindberg's survey, conducted in 1967 in the Palladam area of Coimbatore district, similarly found that only 5 per cent of agricultural labourers were pannaiyaal. But, significantly, he found great variability: in seven of the villages surveyed there were no pannaiyaal, while in one village 26 per cent of agricultural labourers were employed as pannaiyaal (cited in Cederlöf, 1997: 149).

Indeed, the pannaiyaal did not disappear all that swiftly. Describing the labour arrangements on farms in Trichy district in the late 1970s, Athreya et al mention how the pannaiyaal existed alongside casual labourers and contract labourers. The pannaiyaal, however, attended 'to all the routine jobs on the farm (tending livestock, repairing bunds, irrigating fields, and watching crops), and worked alongside the casual workers hired for more labour-consuming tasks like ploughing' (Athreya et al 1990: 134-5). As permanent farm servants, they used to be paid in kind, and while their earnings were below those of casual labourers, they did benefit from certain 'fringe benefits' and forms of security, such as assistance at life cycle rituals and at times of crises, and if lucky the 'gift' of a house-plot by the landlord (ibid.: 133-4). While formally all pannaiyaal were men, women tended to be indirectly employed as house servants, and young boys 
(aged 10-15) typically acted as herdsmen, grazing the cattle and performing all sorts of chores around the farm for an advance paid to their parents (ibid.: 135). Athreya et al found that 5-10 per cent of households were hiring out one or more pannaiyaal, while around 8-9 per cent were hiring in (ibid.: 136-7). By the late 1970s, pannaiyaal clearly still existed, and they continued 'to be bound to their employers by more than an employment contract' (1990: 134). ${ }^{3}$

At around the same time, in the early 1980s, Heyer recorded significantly higher numbers of pannaiyaal in the villages she studied in Coimbatore district, 20-25 $\mathrm{km}$ north of Tiruppur. In 1981/2, 20 per cent of male agricultural labourers in those villages were employed as pannaiyaal (2000: 31). Being at the 'beck and call' of their employers, they worked much longer hours and more continuously than other agricultural labourers but they were paid considerably more than casual labourers taking total pay over the year as a whole. By 1996, the percentage had barely changed (19 per cent), but Heyer's re-study in 2008/9 revealed that only a handful of pannaiyaal were left in the villages (Heyer, 2010). In 2008/9, we similarly found only traces of pannaiyaal labour arrangements in Mannapalayam, one of our study villages $18 \mathrm{~km}$ south of Tiruppur. By now it had become an extremely rare form of labour recruitment, almost entirely replaced by casual and contract labour. In Mannapalayam, the Matharis (lowest Dalit caste) provide the bulk of agricultural labour and the oral histories that we collected illustrate some of the features of the pannaiyaal system in the recent past and testify to its transformation - and ultimate disappearance - over time.

Take the case of Veeran, one of the oldest Mathari men in Mannapalayam, who at the age of 83 , was remarkably eloquent about his life course and his experiences as pannaiyaal. Starting as a herdsman after completing $4^{\text {th }}$ standard, at about the age of 9 , he worked for different Gounder thottamkarar (farmers) in the village under pannaiyaal arrangements. He was responsible for ploughing and irrigating the land, and looked after the cattle. With the exception of a six-year period when he leased land, Veeran always worked as pannaiyaal, never as a casual labourer. In the early years he was paid ragi (millet) but later this became a cash payment. While Veeran stated that he did not get an 'advance' he admitted that 'if we needed money we would ask them, and if we got Rs100, that was a big loan and we would repay Rs 5 at a time! If we worked for one Gounder we wouldn't be allowed to go and work for others; we first had to repay the loan. Pannaiyaal was adimai (slavery)!' While the debt-bond may not have been a central element of the arrangement, it was clearly part of it.

Evidence from elsewhere in Tamil Nadu confirms that there were changes in the way that pannaiyaal were paid during the twentieth century. Cederlöf presents a range of sources that reveal the decline in payments in kind from the 1930s and 1940s onwards, and after the drought of 1947-53 there was certainly a more widespread switch to payments in cash (Cederlöf 1997:145-7). While Veeran mentioned that he used to be paid in ragi (millet) and received one quarter of the

${ }^{3}$ Fieldwork conducted in 1979. 
harvest, he talked as much about the amounts of cash he earned over the years and how he invested or spent it. It is clear from our oral histories that cash began to circulate among both casual agricultural workers and attached farm servants since at least the late 1940s. By the 1960s, cash was more widely available and the higher wages one could earn as a casual labourer made the position of pannaiyaal increasingly unattractive to landless labourers.

But the payment (in cash or kind) was only part of what pannaiyaal received from their landowner. Pannaiyaal farm labourers enjoyed certain urimai (rights), which included in addition to a right to a share in the harvest (varying according to our oral sources between $1 / 3$ and $1 / 4$ of the yield), the right to an annual bonus (in kind and cash) as well as assistance at the time of life cycle rituals and at the time of crises. Veeran, for example, explained that he regularly got loans from Gounder farmers. When he fell sick, aged about 35, he got a loan of Rs 500 from a Gounder for whom he had worked for 3 years. He recalls earning Rs 5 per day at that time (early 1960s), and managed to save Rs10 per week to repay the debt. In addition, when asked what urimai (rights) pannaiyaal used to have, he explained:

'We got money for family functions; they used to give me Rs 200 and some clothes at Diwali, and even now I get this, because of my loyalty. When I fell ill three years ago they gave me Rs 3000 and I don't have to repay it ... They also provided money for the puberty ceremony of my 2 daughters and I got loans of Rs 2000 for each of my daughters' wedding, which I partly repaid ...' Veeran continued the list of support that he used to receive from the Gounder family for whom he worked as a long-term pannaiyaal. Crucially, these rights continued beyond the time of his formal employment as pannaiyaal, and several men and women mentioned that they continued to receive support from their landlords long after they had stopped working for them as a regular farm hand.

In Mannapalayam Veeran is one of the very few men left who worked as pannaiyaal for major parts of their life. His son, now 45, is a casual agricultural worker and has never been attached to a landlord. The stories told to us recount how men typically used to work as pannaiyaal till 5 to 10 years ago, and how since then this form of labour employment has almost entirely disappeared. Veeran's case also illustrates how over the last decades of the twentieth century, the pannaiyaal in this area of the Coimbatore district transformed itself from a life-long bonded relationship into a form of temporary attachment, in which the pannaiyaal attached himself to a landlord for a limited period of time during which he was at the latter's beck and call in return for a combination of cash advances, payments in kind and other forms of support. Clearly, even before its disappearance in the twenty first century, the system had already evolved into a flexible arrangement in which the pannaiyaal would typically receive a cash advance on recruitment, which he would repay at the end of the year (or maximum a few years) in order to move on to another farm. During the period of attachment, the pannaiyaal also received a daily wage in cash, which allowed him to save and repay outstanding debts. 
Moreover, men not only moved between farms and landlords, attaching themselves for increasingly limited periods of time, but they also began to engage in different modes of employment at the same time: as regular work on farms became scarcer a pannaiyaal was allowed to work as a casual day labourer on the farms of other landlords whenever there was no work available on the farm of his master. Indeed, the last remaining pannaiyaal used to have increasingly flexible arrangements with their pannaiyar (employer). The payment they received became the same as that of a casual agricultural labourer, but in reward for their loyalty to the master, the pannaiyaal benefited from more regular work and from the continued right (urimai) in their master's patronage. Increasingly also, men joined a farm as pannaiyaal for a limited period of up to a few years - often until their marriage - after which they preferred the more flexible and better paid arrangement of casual agricultural labourer.

While the importance of pannaiyaal gradually waned and the modes of payment changed, there is also evidence that the role of the pannaiyaal shifted over time. Cederlöf notes that by the late 1960s a pannaiyaal was more like a maistry, someone who supervised other labourers and was like an overseer or trusted servant (Cederlöf 1997: 152-54; Athreya et al 1990: 135). He had a more secure income and a closer relationship with the farmer, stepping in for him in his absence. While he still had to be available whenever the landowner called him, he was able to count on certain rights and 'held a favoured position in relation to the casual labourers employed by the farmer' (Cederlöf 1997: 152-54). In Mannapayalam, Veeran similarly told us that he became responsible for recruiting and overseeing agricultural labourers whenever needed. Comparing the position of pannaiyaal between 1981 and 1996 Heyer notes that their conditions improved: their real wages increased and they had fixed hours of work and leave was agreed in advance. By the mid-1990s employers complained that pannaiyaal left before their contracts were completed, suggesting that the system of advances was no longer sufficient for landowners to maintain control over labourers (Heyer 2000).

Thus, in the last decades of the twentieth century the pannaiyaal itself had become a casual labour institution that allowed Gounder landowners access to a pair of regular and trustworthy farm hands, without preventing workers from selling their labour power elsewhere. Older Matharis did not object to being a pannaiyaal as it no longer prevented them from simultaneously working as a casual labourer for others while providing continued access to 'fringe benefits'.

Employers' discourses, on the other hand, emphasise the arrival of new employment opportunities in the village and the region, and its effects on the local supply of agricultural labour. At one level, Gounder landlords present the ongoing changes in labour relations in ways similar to the landless labourers. Muthusamy, for example, a 76 year old Gounder landowner in Mannapalayam recalls having given Rs 4000 to his pannaiyaal 25 years ago, for his daughter's 
wedding, and since then the latter remained attached to him. The pannaiyaal's wife also used to work for them but that was not binding: whenever she could earn more elsewhere, she would leave the farm. As Muthusamy owned only 3 acres of land, one pannaiyaal was sufficient for him, but it was not uncommon for larger landowners in the area to have multiple pannaiyaal on their farm. Muthusamy explains that the relationship certainly became increasingly monetised and temporary over time: 'because of the advances they received, the pannaiyaal began to shift from one Gounder to the other; they would ask for higher wages and if I didn't pay them more they would go to another landlord and work for him. To get a new pannaiyaal I would have to advance him an extra Rs 1000-2000 ....' But like most Gounders in the villages today, Muthusamy now complains about the difficulty in getting any agricultural labour at all: 'These days, we can't get new pannaiyaal anymore. They all prefer to work in the powerlooms. Since we've had powerlooms in the village, younger men started to go for that and now they no longer want to come for any agricultural work at all!'

This point was made even more forcefully by Natchimuthu (83) and Subbatha, who live on the farm next to Muthusamy's and own 11 acres of land in Mannapalayam. No sooner had we said that we came to talk to them about pannaiyaal Subbatha burst out:

'We had three pannaiyaal working for us, but they've all passed away now! Today nagarikam (urban, modern life) has come and they all go for other jobs, for company jobs [garment work], and we can't find labourers anymore! Now they put a watch and trousers on and go [to town] ... they only work half a day ... they don't come for agricultural work anymore, they don't respect us anymore! ... Today, they use soap and go to Palladam [for work] ... they have all facilities and build their own house ... we can't even call them Chakkliyar [derogative caste name] anymore ... that's how far it has come! ... Now they've got a TV and everything. And they are running off with our money [cash advance] too, and even if we just touch them and ask for it, they put a [legal] case against us, and we lose the Rs 25,000 [paid as advance] and all! ...'

In this spiel, Subbatha contrasts a no doubt romanticised past with a present in which different types of textile work in the region offer local landless Dalits unprecedented access to cash and to alternative sources of income that has reduced their dependency on Gounder landlords. Until not long ago Natchimuthu tried to recruit pannaiyaal by paying increasingly large sums of money in advance, but even this strategy no longer pays off today. Subbatha explains: 'We just can't get pannaiyaal anymore! Now everyone [gets] 100 days of work [under the National Rural Employment Guarantee Scheme], and so they all go for that; there they work for a couple of hours and earn Rs 80 ... but if we need weeding work to be done, we can't get anyone... they now all think of our work as hard work!' ${ }^{4}$ The struggle for Gounder farmers is no longer one of finding

\footnotetext{
${ }^{4}$ Here, Subbatha refers to the National Rural Employment Guarantee Scheme (NREGS) that currently provides rural families with 100 days of work per year, paid at a daily rate of Rs 80 in 2009 .
} 
permanent farm servants, but of attracting any farm hands at all, and many of them now bitterly complain about having to do all agricultural work themselves. Today, Gounders rarely dwell on the disappearance of the pannaiyaal. Instead, they endlessly grumble about the difficulty of finding casual labourers, the high wages they have to pay to attract them, and the limited hours the latter put in. As we will see below, with the arrival of new job opportunities in the region, young Dalit men have indeed lost interest in pannaiyaal arrangements and, to a significant extent, in agricultural work more generally.

As a result, most agricultural labour is now organised by the direct employment of daily labourers for a fixed daily wage ('coolie'), or on what are known as 'contracts' (task-based agreements). Across India today a huge range of contractual arrangements are found, indeed within any village there may be many different arrangements, and within each arrangement there may also be great diversity in terms and conditions, affected by gender, caste and age (see Rogaly 1996). In Mannapalayam certain tasks (such as harvesting and processing tobacco) are generally undertaken on a contractual basis, and in some cases (eg processing tobacco) payment is piece-rate. But, significantly for the purposes of this paper, there is little evidence of workers being employed today on a pannaiyaal basis in this region of Tamil Nadu (Carswell, 2010).

\section{Debt bondage and rural industrial employment}

So what alternative job opportunities are available to landless labourers - many of whom are Dalits - in the region today? The Coimbatore-Tiruppur-Erode belt in Tamil Nadu is highly industrialised. Tiruppur's booming garment industry attracts a wide range of workers who commute on a daily basis from surrounding villages to work in garment companies. One such village is Allapuram, located about $16 \mathrm{~km}$ south-east of Tiruppur, where we also carried out research in 2008-9. Thanks to good bus connections, the villagers of Allapuram have had access to the Tiruppur garment industry since the 1970s. The village high-caste Gounders were the first to go to Tiruppur, where they learned the trade in existing companies, often as supervisors or managers, and later set up their own garment firms. One of Allapuram's Dalit communities, the Paraiyars, similarly have a long history of commuting to Tiruppur for work. ${ }^{5}$ While most of them were initially employed as helpers or checkers in garment companies, they are now working as better-paid tailors, cutting masters, and even labour contractors. Due to a lack of education, long-term dependency on Gounders, and a deeper involvement in the rural economy, the Matharis, the lowest ranking Dalit community in the region, started to commute to Tiruppur much later, and it was not until the 1990s that they began to commute in large numbers. Today, urban garment work also provides this community in Allapuram with more regular work,

\footnotetext{
${ }^{5}$ The Paraiyars are another Dalit community in the region, but they rank higher than the Matharis, are politically better organised and larger numbers of them have enjoyed education and non-agricultural employment.
} 
better wages and above all independence from rural landowners (Carswell and De Neve, forthcoming). In Allapuram, therefore, Dalits have founds ways out of the village, and this has benefited them in substantial ways.

But not all villages in the area have been able to access urban garment work in the same way. Our second study village, Mannapalayam, situated about $18 \mathrm{~km}$ south of Tiruppur, took a rather different path of change. Here, high-caste Gounder landlords began to invest in powerloom workshops within the village from the early 1970s onwards. In a belt of villages west of Tiruppur, Gounders started up small-scale cloth production in an attempt to move away from less profitable agriculture towards more lucrative industrial activity. Powerlooms were set up as a small-scale industry in the village itself, where Gounders built small units on their existing land (often attached to their house) and used profits from agriculture to invest in the purchase of looms and raw materials. Most importantly, as a mode of diversification, powerloom units were run alongside continued cultivation of the land, thus constituting for many Gounders an additional source of income.

While better-off Gounders started rather cautiously with a handful of powerlooms, many of them expanded their units during the 80s and 90 s up to 20-30 looms, and today a handful of Gounders in Mannapalayam own multiple units with up to $50-60$ looms and in once instance 200 looms. Most of them continue to work as jobworkers for urban traders, although some have started up textile trade businesses as well. In Mannapalayam, our household survey revealed that $90 \%$ of the powerloom godowns (workshops) are owned by Gounders, and 96\% of the total number of powerlooms is in their hands. This provides overwhelming evidence that ownership of powerlooms is almost exclusively the privilege of Gounders in the village, reflecting the wider pattern of the region. That powerloom cloth production is an additional activity for most Gounders appears from the fact that $63 \%$ of powerloom owners in Mannapalayam are also landowners. And, vice versa, $67 \%$ of landowners also own powerlooms.

Local traders based in nearby towns provide the cotton yarn and buy the final plain cloth, which is further processed in Erode, traded across India, and finally sold on both domestic and export markets. Powerlooms are a labour-intensive industry and labour was by and large recruited in three stages. The first units in the village were largely operated with family labour. The powerloom owner, his wife, sons and daughters, and other close kin would run the looms and teach each other the tricks of the trade. Godowns were established both inside the village and on the thottams (farms) around the village. Soon units began to expand and some time in the late 1980s a night shift was introduced to increase production. As a result, family labour ceased to be adequate and powerloom operators had to be recruited from outside the immediate family: initially fellow Gounder caste members were the preferred recruits, but soon local Matharis, the main Dalit community in the village, were employed too. For the landless Matharis, it offered first-time access to non-agricultural work within the village as 
well as access to a more regular source of income, especially in comparison with increasingly irregular and unpredictable casual work in agriculture. Finally, as the industry boomed during the 1990s and the local Mathari labour supply became insufficient, powerloom owners began to attract migrant workers from nearby districts. Some migrants came as individuals but many migrated as a household and have now several household members working for the same employer. Migrant workers belong to different communities, including caste Hindu and Christian communities as well as Dalits. Most of them came from rural backgrounds and had little or no exposure to industrial work before migrating to the area, although some may have worked in godowns in neighbouring villages before moving to Mannapalayam. Most moved to the area in search of work, some specifically looking for advances to meet urgent cash needs back home.

In Mannapalayam, all migrant workers are provided with accommodation on site, which nowadays includes supplies of electricity and gas, and for some also a gas stove and TV. Because they live in accommodation provided by their employers, migrant workers remain under close and constant supervision of the Gounders. Today the migrants make up a large part of the powerloom workforce in Mannapalayam: $70 \%$ of powerloom workers are migrants, while $30 \%$ are locals. Caste-wise, 14\% of the workforce are Gounders (all of whom are migrants), $51 \%$ are Dalits, and $34 \%$ belong to other castes. ${ }^{6}$ Gounder powerloom owners act very much like Gounder landowners: they supervise labour on the shop floor while working alongside them as they used to do in the fields (Chari, 2004). The Gounder owner or his son might do a nightshift whenever an operator fails to turn up, or his wife might stand in if an extra person is needed for cone winding.

Labour shortage, however, remained a perennial problem. The ever-expanding powerloom industry in the villages enhanced competition between Gounders for powerloom operators, while garment jobs in Tiruppur, with their higher earning potential and much valued freedom, attracted ever larger numbers of rural commuters from the 1980s onwards (Carswell and De Neve, forthcoming). In this context of rapidly tightening labour markets in the region, Gounder powerloom owners started handing out cash advances to attract new sections of the regional labour market, to retain their hold over 'old' village labour, and to prevent a complete labour drain to town. It was through debt that Gounder employers sought to bind labour to their powerlooms. It is not entirely clear when exactly advances began to be handed out, but there is ample evidence that employers became more generous with advances once the local pool of labour was exhausted and the need to tap into migrant labour markets became more pressing. Many local Matharis see a link between the arrival of migrant workers and the introduction of cash advances, and below we provide evidence that lends considerable support to these Mathari claims. The more systematic handing out of cash advances probably started somewhere in the early 1990s.

\footnotetext{
${ }^{6}$ This excludes those who work their own looms.
} 
Initially, cash advances did not exceed Rs 500 or Rs 1,000, but over the years the amounts escalated rapidly. By the time we carried out field research in 20089 , powerloom workers routinely received Rs $30,000-40,000$ as an advance. We even came across families who had received up to nearly Rs 100,000 as an advance, but in such cases at least 2 or 3 members of the household would work for the same employer. In our Mannapalayam survey, 83\% of powerloom workers had received an advance in 2009. Breaking this down further: $89 \%$ of loom operators had received an advance and $73 \%$ of cone winders. This difference reflects the importance of loom operators versus cone winders in the industry. As cone winding is a female, more flexible and day-time job, it can always be done by a woman in the owner's household. Yet, even so, women cone winders receive substantial advances these days. Of the workers who received an advance, the average amount received was Rs 27,729 (or, an average of Rs 28,597 for powerloom operators and Rs 21,000 for cone winders). The smallest advance we came across in 2009 was Rs 3,000 and the largest amount reported was Rs 90,000.

While initially village Matharis received no advances on joining as powerloom workers, they too were soon given cash on recruitment. Employers admit that they had no choice: if they did not start handing out cash advances to local Matharis, they would by now all be working in the Tiruppur garment industry. Today most local Mathari workers have received advances, and indeed there is little difference between the percentage of local Mathari workers (i.e. nonmigrants) with advances (80\%) and the percentage of migrant workers with advances (84\%). ${ }^{7}$ But local Matharis do have smaller advances than other groups: they have Rs 22,157 as average outstanding advance, compared to Rs 32,947 for migrant Dalits, Rs 29,583 for migrant Gounders and Rs 24, 652 for other castes. This reflects the local Gounders' continuing extra-economic grasp over the local Mathari labour force.

To grasp the real value of these cash advances, we need to compare them with wages earned. Powerloom operators are paid piece-rates and work in two shifts: a day shift of 11 hours and a longer night shift of 13 hours. Operators work alternate weeks of six day shifts followed by six night shifts. Loom operators earn about Rs 170 per day shift and about Rs 200 per night shift, totalling between Rs 1000 and Rs 1200 per week. Allowing for the rather frequent leaves, interruptions and work stoppages, loom operators' annual income amounts to about what they get as an advance. Women generally work as cone winders, because working as an operator involves night shifts, which is deemed socially unacceptable for women unless they can work alongside a relative. Cone winders prepare cones for the powerlooms and can follow flexible working hours during the day, making it easy to combine with domestic work. Cone

\footnotetext{
${ }^{7}$ The group with the highest percentage of advances are Gounder migrants (92\%) and Dalit migrants (90\%). Being at opposite ends of the caste hierarchy it is clear that it is their migratory status that is particularly important here.
} 
winders receive a daily wage ranging between Rs 50-100, and for them, the average cash advance tends to exceed the average annual income.

As a consequence, the current level of cash advances prevents most powerloom workers from repaying their employers - be it at the end of the year or in the long run. Debt thus ties workers to employers for indeterminate periods of time. Rather than being repaid, debts tend to go up over time as workers frequently ask their employers for top-ups to meet various household needs. Employers rarely refuse as they fear losing their workers to other units in Mannapalayam or nearby villages. This fear is grounded in experience given that powerloom workers do regularly shift between units, transferring their debt with them. They pay back one employer with the advance they receive from another. While this strategy might free them from a particularly unpleasant or over demanding employer, it does not free them from being tied to rural powerloom work and to the dominant caste of Gounders, and indeed gets them gradually deeper into debt. Debt bondage in the powerloom industry functions as a new tool in a longstanding and ongoing search by a high-caste rural elite for control over low-caste labour.

\section{Dependency imposed and experienced}

To understand how debt bondage is experienced in the powerlooms, we need to turn to what employers and workers themselves have to say about it. We begin with the employers. While carrying out our fieldwork in 2009, Gounder powerloom owners bitterly complained about the difficulty of finding adequate labour in a tight labour market and despaired that despite high advances they were unable to get and hold onto sufficient workers. Subramaniam, the only owner of 200 powerlooms in the village, argues that the situation in Mannapalayam is worse than in Mumbai: 'In Bombay you can get workers at any time, but here we can't get labour!' The main reason, he claims, is that they are close to Tiruppur, where all villagers now prefer to work. Nataraja, a man in his early 30s who runs 24 looms together with his three brothers, says that the practice of giving ever larger advances has largely backfired: 'some people get a big advance and then they come here and see the latest cell phones and ask for an extra loan to buy one and then they leave the village and we lose the money!' Without being prodded, Nataraja continued to compare migrant workers with local Matharis, a comparison that is widely reflected on by different employers:

The locals won't come regularly; they will often take a day off and we have to go to their houses and call them to the godown. They will also use the PCR Act against us as soon as we make a comment. The outsiders (veliyur aal) work more regularly as they stay with us, but then there are cases of migrants running off with advances ... and we can't trace them or get the money back ...'

On balance, Gounders agree that while local Matharis are less likely to run off with large sums of money, they are harder to discipline and control on an 
everyday basis. They often do not turn up for work in the mornings and Gounders find it extremely humiliating to have to go to the Dalit colony to call workers from their houses. Migrant workers, on the other hand, are seen as more reliable on a day to day basis, if only because they live on the compound and can't easily leave. However, they are also considered more risky as they may always run off without repaying the advance, and more expensive as extra facilities (such as housing, electricity, etc) have to be provided. But Nataraja, like many others, admits that the problem is compounded by competition between employers over labour, which manifests itself in the poaching of workers: 'when an employer hears of a good worker, he will call him to his unit when they meet in the street and he will promise him a higher advance to try and get him'. Indeed, the relationship between the village Gounders is rather ambivalent: while at one level they collaborate to prevent workers from searching work in town (see below), at another level, competition between them over labour has become very intense.

The choice of locals versus migrants is also shaped by at least two other factors, one of which is the spatial separation between village centre and surrounding farms. Gounders in the centre of Mannapalayam continue to rely on Matharis from the village colony across the road. Gounders whose looms are in the thottams (farms) around the village, on the other hand, complain that the Matharis from the colony won't come to work in their looms and that is why they started to recruit outsiders. We observed that there are indeed fewer Matharis working in the powerlooms on the farms, and fewer migrants in the centre of the village. Another and increasingly significant reason why some employers are hesitant to recruit local Matharis has to do with Matharis' heightened political awareness as reflected in their use of the PCR Act, as mentioned by Nataraja above. Local Matharis have begun to use the SC/ST (Prevention of Atrocities) Act, which is part of the Protection of Civil Rights Act (PCR Act), to protect themselves against abuses by caste Hindus. A number of cases were running against Gounders in the village at the time of our research, and these clearly acted to dissuade powerloom owners from employing Matharis. Thangaveel, a powerloom owner located in the centre of Mannapalayam, describes the current situation in a typical manner:

Workers get large advances of at least Rs 30,000 per person and in

Somanur even up to Rs 1 lakh. They get lots of money but when we ask it back or we simply ask them to come and work, they claim that we shout at them and they put a [legal] case against us ... they have now got into the habit of putting false cases!

Arjun, a local farmer and ex-powerloom owner, concludes it this way: 'the workers have become clever (veekanam); compared to us they have become cleverer; they refuse to do unnecessarily difficult work... they work for what they need and then go home...these days, they can spend without worries!' What such statements reveal is that Gounders are not only realising that workers may seek to prioritise their own interests and aspirations over those of their employer, 
but also that they have lost some of their earlier (caste-based) abilities to enforce compliance and commitment.

While Gounders by and large present a picture of a collapsing moral economy in which generous and caring employers are being let down by greedy and lazy workers, the latter tell us a different story. Powerloom workers are fully aware that they've ended up in a situation of bonded labour, and refer to themselves with the Tamil terms adimai (slave) or kottadimai (bonded worker). Today, Mathari powerloom workers cannot repay the astronomical amounts they are given, and it is debt bondage that now ties them to their employers 'as slaves' (adimai madri). They realise that even though they may be able to shift between individual employers, they remain tied to powerloom work and to the community of Gounders. While employers argue that workers only change employers to make more money, for the workers getting higher advances only means getting deeper into debt.

So, why then, do Mathari and migrant workers accept these cash advances in the first place, and why do they allow their outstanding debts to grow over time? In a context where credit from private money lenders comes at an extremely high price, access to an interest-free lump sum of money is difficult to resist, especially when faced with unexpected life crises. Raja, a young powerloom operator says with despair: 'there is no other way: if I have an urgent family problem and I need Rs 10,000, I ask my employer for the money and he will add it to my outstanding debt. I know that my kadan (loan) will go up and that I won't ever be able to repay, but there is no other way .... While there is no doubt that some Matharis spend their advances on unproductive consumption, such as colour TVs and motorbikes, three other areas of spending emerge from our village survey. First, considerable amounts of money are spent on health-related crises, either of their own or extended family. Second, marriage expenses have increased in the area and, together with expenses on other life cycle rituals, absorb ever larger sums of money. And, thirdly, many informants have made substantial improvements to housing over the last couple of decades (see also Heyer 2010). Local Matharis have invested in houses within their colony, while migrants have bought land back home to build houses on. Some migrants also invest in agricultural activities, particularly back home.

What these areas of spending reveal is that people have duties of different sorts, and that they may prioritise some duties over others even if this results in rising debts. While labourers' outstanding debt amounts to a duty to their employers (debt, etymologically, comes from the French 'devoir', carrying a sense of 'duty' or 'something owed'), ${ }^{8}$ they also have duties towards others, such as family and friends, whose needs and interests they are equally committed to. Debt is not merely economic, it has a social life too. What we observe is that when powerloom workers take on a debt - and when they ask for further advances over time - they are in fact prioritising their obligations (debts and duties) to

\footnotetext{
${ }^{8}$ Thanks to Karen Sykes for her helpful ideas on debt.
} 
family and kin (e.g. organising a wedding, paying a dowry, or attending to ill health) over and above anything else. In prioritising these obligations to their relatives and kin they are willing to suffer the condemnation of their employers, such as accusations of being lazy and untrustworthy. Such condemnations thus result from them putting their duty to their kin above their duty to their employer (to repay their debt). While initially many hope that one day they will be able to settle their debts - and thus meet both types of obligations - in reality few of them manage to do so. The result is more likely to be a deepening of financial debts over time and a gradual realisation of being trapped in debt bondage. It is this realisation that now keeps younger Matharis away from both cash advances and powerloom work, and that leads them to fulfil familial obligations through new avenues, as discussed below.

As is the case elsewhere, powerloom workers are bonded to extremely unpleasant worlds of industrial work (Picherit 2009; Guérin et al 2009; Roesch et al 2009). Powerloom workers complain about the long hours and the alternating weeks of day and night shifts that affect their health. They work on average 12hour shifts for earnings that barely touch Rs 200 per day. As one young man put it: 'here we work 12 hours for Rs150, while in Tiruppur we can earn the same amount in an 8-hour shift, and there if we work till midnight, we get a double shift paid!' Powerloom workshops are dusty and noisy, accidents with shuttles flying out of looms are not uncommon, and the constant standing up at the looms is tiring for even the youngest and healthiest men. 'We are inhaling dust all the time and by the end of the shift our shirts are completely black from leaning against the looms', one loom operator explained. In addition, the godown - a Gounder-dominated territory - remains a site of caste discrimination, with Matharis routinely mentioning the separate drinking glasses and the restrictions on entering the Gounders' houses. ${ }^{9}$ Equally depressing is the constant surveillance they are subjected to as Gounders hassle them to come to work even on days that they are unwell, exhausted or bound by family responsibilities. Matharis tell about how they are shouted at and even beaten if they fail to appear at work or obey Gounders' orders. They realise that by taking on advances they have lost control over their own labour and lost the freedom to go and work elsewhere - they have effectively become de-proletarianised as described by Brass $(1990 ; 1994)$. Even if debt itself does not necessarily turn a worker into a bonded labourer, the ties and treatment that come with it certainly do (Roesch et al 2009).

The availability of attractive alternatives in nearby Tiruppur further intensifies the Matharis' feeling of being 'tied' to the Gounders and 'trapped' in powerloom godowns, and enhances their desire to break out of the village. Especially among the younger Mathari men of Mannapalayam, there is an overwhelming desire to take up garment work in Tiruppur and escape the bonds that currently tie them to the village Gounders. Apart from the obvious attractions of being free to search for work as and when they like, garment work is widely considered a

\footnotetext{
${ }^{9}$ See Carswell and De Neve, T-shirts and Tumblers.
} 
cleaner, better-paid and more sophisticated type of employment. Garment work is associated with urban life and what is locally called nagarikam or modern, urban sophistication. Mathari boys express it this way: 'when we study up to $9^{\text {th }}$ or $10^{\text {th }}$ standard, we don't want to work in powerlooms; we prefer tailoring work; then we can sit down at a table with a chair and we don't have to stand up and there is no dust.' Indeed, young men with levels of schooling beyond primary education tend to either seek self-employed work (starting up cycle workshops or electrical work) or garment work in Tiruppur. Moreover, as one young Mathari put it, 'in Tiruppur we haven't got that caste problem (jati pritchenai) either.' Tiruppur is known as a place where urban anonymity and mixing has made caste much less relevant and where the forms of discrimination still present in the village have largely disappeared.

In several discussions with groups of young Mathari men in the colony, we were told that 'if we had a direct bus [to Tiruppur], we would all be working there! It's only because it's difficult to get there that we stay here, otherwise nobody would work in the village! And we have no motorbikes to get there on our own.' The Matharis blame the Gounders for blocking a direct bus link between the village and Tiruppur. And the Gounders themselves admit that they have prevented a direct bus, and that if they were to allow one they would have no workers left in their powerlooms.

However, poor transport is only part of the story, and probably not even the most important part at that. The main reason why young men fail to quit powerloom work and leave the village is debt bondage, especially for men and women now in their 30s and 40s, who have accumulated debts of Rs 30,000 to Rs 50,000 . If they were to leave their employer without repaying the debt, they would fear at best the humiliation of having the Gounder knocking daily at their door and shouting abuse, and at worst the concerted opposition of the village Gounders which can result in the use of intimidation and even physical violence against their entire family. As such, very few Matharis tied by advances consider it a viable option to run off and take up work in Tiruppur. With their family based in the village, it is simply too dangerous to leave a local employer without repaying one's outstanding debts. Moreover, as cash advances are not paid in the Tiruppur garment industry, powerloom workers cannot transfer a debt from a rural powerloom unit to an urban garment company.

So, is this acute consciousness of debt bondage turned into acts of resistance? Is anybody able to 'break out' of the ties that bind them? The first and most prominent form of resistance is found among young Mathari men, who increasingly avoid powerloom work altogether and refuse to take on cash advances. These unmarried men, in their late teens or early twenties, actively avoid entering powerloom work or accumulating debts through it. A small but growing number of them commute to Tiruppur for garment work. Being unmarried they can spend long days away from the village and take multiple buses to travel back and forth. For them, Tiruppur is an attractive place as it 
holds considerable promises in terms of access, wages, long-term career options and freedom from the sorts of ties that bind them in the village. But high levels of indebtedness, a lack of transport facilities, and a lack of skills (which mean they have to start work as a lowly paid 'helper') means that so far only a handful of Matharis commute to Tiruppur, evidenced by the fact that in 2009 no Mathari household in Mannapalayam had garment work as a primary source of income. Nevertheless, the recent success of some young Mathari men in Tiruppur is significant. Their confidence that success in the urban economy is possible inspires others to steer away from powerloom work and from accepting ever larger advances. It creates awareness that urban employment can be a source of livelihood, independence and progress, and on leaving school, many more young Mathari men are likely to join the urban commuters to Tiruppur.

Apart from seeking to avoid powerloom work altogether, Matharis have begun to resist Gounder domination by other means. As mentioned above, over the last ten years, they have used the SC/ST (Prevention of Atrocities) Act against the Gounders as a legal tool to ward off some of the most extreme forms of caste discrimination and oppression, and to protect some basic rights. The use of the Act has had a far-reaching impact on social relations in the village and Gounders today complain extensively that the status quo is being challenged. Several PCR cases (as they are known locally) had been put in Mannapalyam in the last couple of years, including one against the Panchayat President, and Gounders talked incessantly of how the Act was 'scaring them' and forcing them to 'speak with respect'. Although they openly admitted bribing the police to drop cases, it is clear that the Act is now widely used in the powerloom belt around Tiruppur and that it has provided Matharis with a new tool in their struggle against systematic economic subordination and social discrimination that Gounders seek to maintain through the forms of labour bondage described in this article.

\section{Conclusion}

Despite India's ever deeper integration into global production networks, and despite widespread government support for neo-liberal economic policies, practices of bonded labour have not disappeared from the subcontinent. Some scholars have argued that capitalism and unfree labour are incompatible in the long run and that under maturing capitalism unfree labour will ultimately be replaced with free wage labour (Rao 1999). However, this case study on the rural powerloom industry in southern India illustrates how - even under mature modes of capitalist production - unfree labour relations can not only persist, but can become even more entrenched over time (Srivastava 2009). Moreover, as illustrated by the case of the Tiruppur region in western Tamil Nadu, even at the heart of a highly industrialised region that is deeply integrated in global production networks and is marked by tightening labour markets, debt bondage remains a powerful tool through which rural employers seek to recruit and retain both a local and a migrant labour force. 
Lerche (2007) urges us to explore the relationship between unfree labour and capitalist development, and suggests that forced and unfree labour has to be understood in terms of the highly uneven trajectories of capitalist development across the globe. Our material takes this further and suggests that uneven development also needs consideration at a regional level. In the booming Tiruppur textile region, rural powerloom workshops compete for labour with advanced urban garment firms that are more directly integrated into global production networks. In this competition, rural employers not only take recourse to migrant workers but also introduce new forms of debt bondage through which they seek to secure a stable labour force. Uneven capitalism requires uneven modes of labour deployment. Pouchepadass reminds us of this when writing 'that while labour in capitalism is by definition commodified, this commodification may take on many different forms and a working class comprising slaves or forced labourers as well as wage-earners and other free workers is not necessarily inconsistent with the rational capitalist division of labour' (2009: 37). In the Tiruppur industrial region, competition between employers over labour leads to different modes of labour recruitment, of which bonded labour is just one amongst many.

In some rural industries, such as cane cutting or brick kilns (Guérin 2009; Guérin et al 2009; Picherit 2009), relations of unfree labour and debt bondage have become increasingly time-bound, or at least limited to a particular season or task. In the powerloom industry, by contrast, relations of unfree labour are anything but short-lived: they usually extend over years, and often even over decades. It is in this sector of the rural economy that advances tie workers indefinitely, that is, until the outstanding debt is repaid. While a few lucky ones may one day be able to repay their debts, the majority never manage to buy themselves free and access more attractive industrial jobs in the region. It carries some irony that the so-called 'old' form of bondage in this region of south India - that of pannaiyaal (permanent farm servant) - became a more temporary, flexible and casual institution over time, while the 'new' form of unfree labour as we find it in the rural powerloom industry, has produced much more durable ties of unfreedom.

However, the strong forms of bondedness, and the effective de-proletarianisation of labour that it has brought about (Brass 1990; 1994), has not entirely succeeded in curbing the rise of an overt awareness among workers of their bondedness. Across the powerloom belt of western Tamil Nadu, strong and persistent ties of unfree labour are accompanied by high levels of consciousness among powerloom workers and by explicit acts of opposition, be it in the form of avoidance or litigation. This consciousness has not only emerged from gradually increasing levels of formal education among low caste labourers but also from the availability in the region of a range of urban, industrial employment opportunities that draw ever larger numbers of young village men and women to town. It is their awareness of, and proximity to, these new urban opportunities largely absent in many other parts of rural India - that have made the youngest generation of Dalits in this region increasingly conscious of their current position. Dalit workers openly express their aversion to the current debt practices that 
have come to tie them to employers, and it is the generation of young Dalit men who now seek to avoid entering powerloom work altogether and instead try to access garment work in nearby Tiruppur. Recently, some of the youngest Matharis have managed to stay away from powerloom work and to make a successful entry into the Tiruppur garment industry. The example they have set is tremendously powerful. Even though they are still few in numbers, these young men's successful escape from the village, from powerloom work and from Gounder dependency carries a huge symbolic meaning for their fellow caste members and sets an example of the sorts of future freedoms that may become accessible to ever more of them. Even if regional uneven development causes bonded labour to be reproduced over time, it is this same unevenness that also raises awareness among bonded workers of more attractive free wage alternatives nearby and that may encourage bonded workers to avoid the ties of bondage in future. And this, surely, must be a cause for cautious optimism.

\section{Bibliography}

Athreya, V.B. et al. (1990). Barriers Broken: Production Relations and Agrarian Change in Tamil Nadu. New Delhi: Sage Publ.

Basu, R.S. (2009). Entrapped between Bondage and Freedom: Paraiyans and the Changing Fortunes of Agrestic Servitude in Colonial and Post-Colonial Tamil Nadu. In Breman, J. Guérin, I. and Prakash, A. (eds), India's Unfree Workforce: Of Bondage Old and New. New Delhi: Oxford University Press.

Brass, T. (1990), Class Struggle and the Deproletarianization of Agricultural Labour in Haryana (India)', The Journal of Peasant Studies, 18(1): 36-67.

Brass, T. (1994). 'Some Observations on Unfree Labour, Capitalist Restructuring, and Deproletarianization', International Review of Social History, 39(2): $255-275$.

Brass T (1999) Towards a Comparative Political Economy of Unfree Labour: Case Studies and Debates London: Frank Cass

Brass, T. (2008). 'Capitalism and Bonded Labour in India: Reinterpreting Recent (Re-)Interpretations' The Journal of Peasant Studies 35 (2): 177-248.

Breman, J (1993) Beyond patronage and exploitation: Changing agrarian relations in South Gujarat. New Delhi: Oxford University Press.

Breman, J. Guérin, I. and Prakash, A. (eds) (2009). India's Unfree Workforce: Of Bondage Old and New. New Delhi: Oxford University Press. 
Breman, J. and Guérin, I. (2009). Introduction: On Bondage: Old and New. In Breman, J. Guérin, I. and Prakash, A. (eds), India's Unfree Workforce: Of Bondage Old and New. New Delhi: Oxford University Press.

Chari, S (2004), Fraternal Capital: peasant-workers, self-made men and globalization in provincial India Stanford University Press, Stanford.

Carswell, G. (2010) 'Not working for export markets: work, agency and livelihoods in the Tiruppur textile region'. Paper presented at Sussex Workshop, July 2010

Carswell, G and De Neve, G. (forthcoming) T-shirts and Tumblers: Caste, Politics and Industrial Work in Tiruppur's Textile Belt, Tamil Nadu. Contributions to Indian Sociology, under review.

Cederlöf, G. (1997). Bonds Lost: Subordination, Conflict and Mobilization in Rural South India, c.1900-1970. New Delhi: Manohar Press.

De Neve, G. (1999). Asking for and giving baki: Neo-bondage, or the interplay of bondage and resistance in the Tamilnadu power-loom industry. In Jonathan P. Parry, et.al, (eds) The Worlds of Indian Industrial Labour. New Delhi: Sage Publications.

ESRC Unfree Labour Seminar Series Papers, 2009

Guérin, I. (2009). Corridors or Migration and Chains of Dependence: Brick Kiln Moulders in Tamil Nadu. In Breman, J. Guérin, I. and Prakash, A. (eds), India's Unfree Workforce: Of Bondage Old and New. New Delhi: Oxford University Press.

Guérin, I. et al (2009). Neo-bondage, seasonal migration and job brokers: Cane cutters in Tamil Nadu'. In Breman, J. Guérin, I. and Prakash, A. (eds), India's Unfree Workforce: Of Bondage Old and New. New Delhi: Oxford University Press.

Heyer, J. (2000). 'The Changing Position of Agricultural Labourers in Villages in Rural Coimbatore, Tamil Nadu, between 1981/2 and 1996', QEH Working Paper 57, December 2000.

Heyer, J. (2009). 'The Marginalisation of Dalits in a Modernising Economy', in B. Harriss-White and J. Heyer, The Comparative Political Economy of Development Africa and South Asia. Routledge: London.

Heyer J (2010a) The Political Economy of Development in an Industrialising Region of South India. Paper presented at the "Celebrating Gavin Williams" conference, Oxford University Department of Politics and 
International Relations and Department for International Development, 910 July 2010.

Heyer J (2010b) The impact of 'Tiruppur' on the lives of women and children in rural areas in the Tiruppur region. Paper presented at Sussex Workshop, July 2010

International Labour Organisation (ILO) (2005) A Global Alliance Against Forced Labour. ILO: Geneva.

Kapadia K. (1995) The profitability of bonded labour: The gem cutting industry in rural South India Journal of Peasant Studies 22(3): 446-483.

Lerche, J. (2007). A Global Alliance against Forced Labour? Unfree Labour, NeoLiberal Globalization and the International Labour Organization. Journal of Agrarian Change 7(4): 425-52.

Picherit, D. (2009). 'Workers Trust Us!' Labour Middlemen and the Rise of the Lower castes in Andhra Pradesh. In Breman, J. Guérin, I. and Prakash, A. (eds), India's Unfree Workforce: Of Bondage Old and New. New Delhi: Oxford University Press.

Pouchepadass J. (2009). After Slavery: Unfree Rural Labour in Post-1843 Eastern India. In Breman, J. Guérin, I. and Prakash, A. (eds), India's Unfree Workforce: Of Bondage Old and New. New Delhi: Oxford University Press.

Rao J.M. (1999). Agrarian power and unfree labour. Journal of Peasant Studies 26(2): 242-262.

Roesch, M., Venkatasubramanian, G. and Guérin, I. (2010). 'Bonded Labour in the Rice Mills: fate or Opportunity? In Breman, J. Guérin, I. and Prakash, A. (eds), India's Unfree Workforce: Of Bondage Old and New. New Delhi: Oxford University Press.

Srivastava R. S. (2005). 'India: Internal migration and its links with poverty and development', in Migration, Development and Poverty Reduction in Asia. Geneva: International Organization for Migration.

Srivastava R.S. (2009). Conceptualizing Continuity and Change in Emerging Forms of Labour Bondage in India. In Breman, J. Guérin, I. and Prakash, A. (eds), India's Unfree Workforce: Of Bondage Old and New. New Delhi: Oxford University Press. 
Washbrook D (1993) 'Land and labour in late eightennth-century South India: The Golden Age of the Pariah?' in P. Robb Dalit Movements and the meanings of Labour in India Oxford University Press, Delhi. 